\title{
Urgences
}

\section{La lunaction (illustrations de Pauline Veilleux)}

\section{Bernard Boucher}

Numéro 4, 2e trimestre 1982

URI : https://id.erudit.org/iderudit/025056ar

DOI : https://doi.org/10.7202/025056ar

Aller au sommaire du numéro

Éditeur(s)

Urgences

ISSN

0226-9554 (imprimé)

1927-3924 (numérique)

Découvrir la revue

Citer ce document

Boucher, B. (1982). La lunaction (illustrations de Pauline Veilleux). Urgences, (4), 23-34. https://doi.org/10.7202/025056ar d'utilisation que vous pouvez consulter en ligne.

https://apropos.erudit.org/fr/usagers/politique-dutilisation/ 


\section{BERNARD BOUCHER}

\section{La lunaction}

(Illustrations de Pauline Veilleux) 


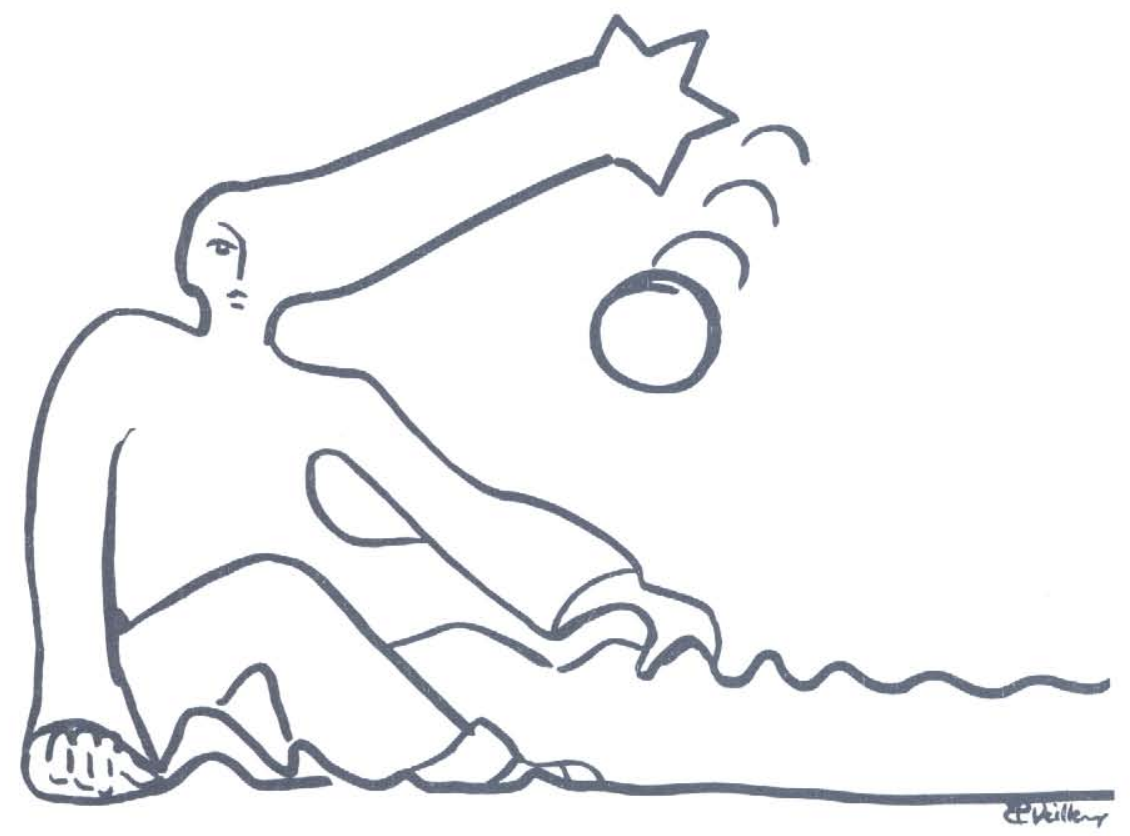




\section{LA LUNATION}

repos des yeux

sur l'altitude illustre

des lignes à mains nues

gestes essentiels

poursuites des intuitions

sous encre intemporelle

l'arbre de nuages

route des Chagall

comme terre et eau

sève des images

perle la caverne cervicale

terreau de montagne

volière de soie

interrogent le fil. 


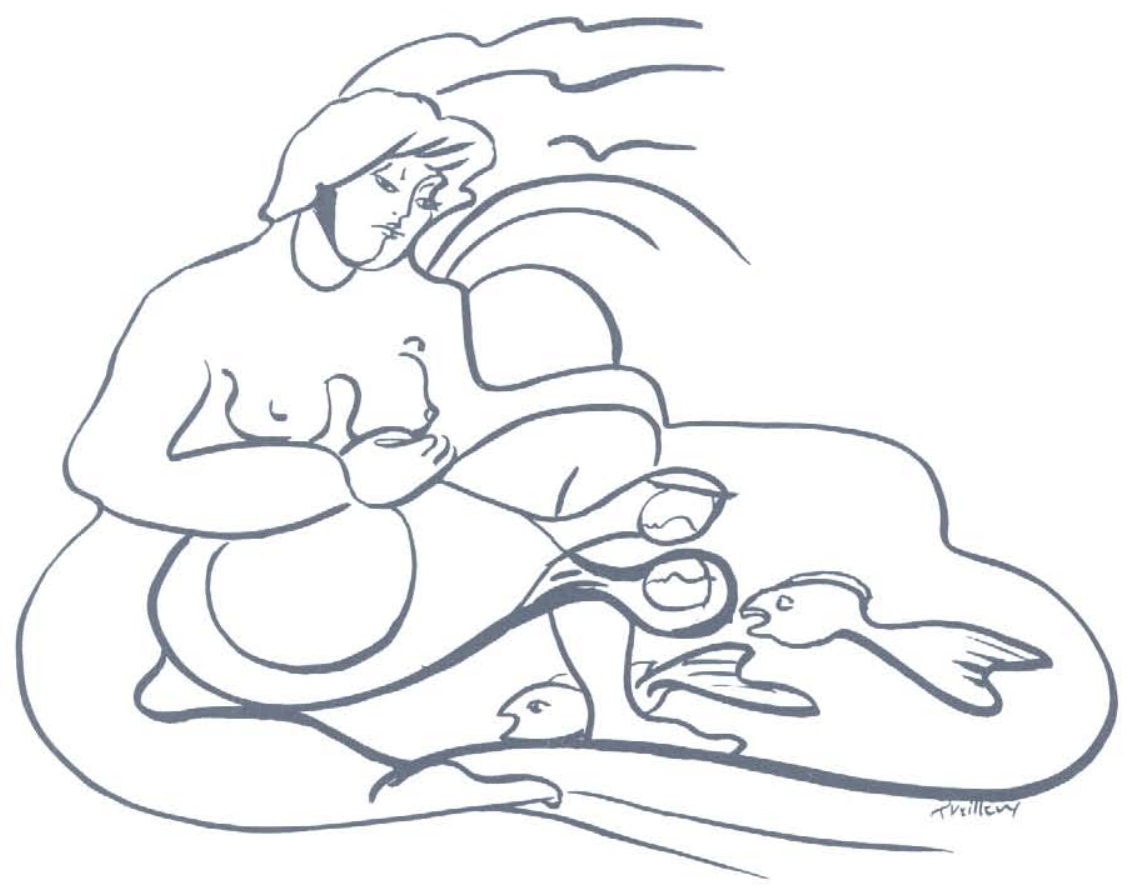


LA LUNACTION 
crayons de couleur

sur le papier

de la tendresse

tes mains 
remettre en jeu

des menottes terreuses

m'attachent

I'avion de questions

creuse les nuages 
des nuages défilent sans réponse

le discours

des mains s'ajuste

le temps s'ajoute 
4

les mots ne sont pas

de la lumière

interdit les recels d'images

ne touche pas la terre

serait-elle viable

sans cocon et transhumance 
baïonnette des tendres

coeurs sur la braise

au bruissement d'un sourire 
6

allons vers la mer tendre le regard du silence 
la dentelle de tes insomnies assise au rivage des lunes

toise pour nous des éternités 